\title{
Web blight (Thanatephorus cucumeris): a new disease on leaves of okra plants
}

\author{
Mancha areolada (Thanatephorus cucumeris): \\ nova doença das folhas do quiabeiro
Luadir Gasparotto', Cristiaini Kano ${ }^{2 *}$, Paulo Ceresini ${ }^{3}$, José Pereira', Marinice Cardoso ${ }^{1}$, Danilo Pereira ${ }^{3}$, Vanina Castroagudín ${ }^{3}$

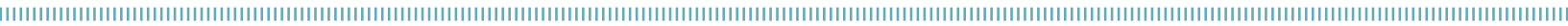

\begin{abstract}
In an experiment on organic production of okra (Abelmoschus esculentus (L.) Moench) that was carried out from September 2013 to January 2014, in Manaus, Amazonas state, Brazil, we observed large chlorotic, necrotic, helical, discontinuous, dark or light-brown lesions with partial detachment of the injured area on the adaxial surface of leaves located in the median and basal portions of the plants. A whitish mycelium mantle covers the lesions on the leaves at the abaxial surface at high moisture conditions. Using morphological characteristics, Koch's postulates, and phylogenetic analyses of the ITS-5.8S rDNA region, we identified that the fungus causing the lesions on the okra leaves was Thanatephorus cucumeris (Frank) Donk (asexual stage of Rhizoctonia solani Kuhn of the anastomosis group AG-1 ID). This is the first report of T. cucumeris causing web blight on okra in Brazil, and probably in the world. So far, $T$. cucumeris was described on okra only on post-harvest pods rotting and seedlings' damping off.
\end{abstract}

KEYWORDS: Thanatephorus cucumeris; Abelmoschus esculentus; etiology; Amazon.
RESUMO: Em um experimento sobre a produção orgânica do quiabeiro (Abelmoschus esculentus (L.) Moench), que foi instalado em Manaus, Amazonas, Brasil, no período de setembro de 2013 a janeiro de 2014, observou-se, na face adaxial do limbo foliar das folhas medianas e baixeiras, a ocorrência de lesôes cloróticas e necróticas grandes, helicoidais, de coloração marrom escuro ou marrom claro e descontínuas, com desprendimento parcial da área lesionada. $\mathrm{Na}$ face abaxial, sobre as manchas, em condiçôes de alta umidade, constatou-se a presença de um manto micelial esbranquiçado do patógeno, facilmente visível, recobrindo a área colonizada. Por meio da análise de características morfológicas, postulados de Koch e análise filogenética da região ITS-5.8S do rDNA do fungo isolado, identificou-se Thanatephorus cucumeris (Frank) Donk (fase assexuada Rhizoctonia solani Kuhn grupo de anastomose AG-1 ID) como o agente causal da doença. Este é o primeiro relato de T. cucumeris causando mancha foliar em quiabeiro no Brasil e, provavelmente, no mundo. Até então, sua ocorrência em quiabeiro estava restrita à podridão pós-colheita em frutos e tombamento de mudas.

PALAVRAS-CHAVE: Thanatephorus cucumeris; Abelmoschus esculentus; etiologia; Amazônia.

'Empresa Brasileira de Pesquisa Agropecuária (Embrapa) - Manaus (AM), Brazil.

${ }^{2}$ Empresa Brasileira de Pesquisa Agropecuária (Embrapa) - Campinas (SP), Brazil.

"Universidade Estadual Paulista "Júlio de Mesquita Filho" (UNESP) - Ilha Solteira (SP), Brazil.

*Corresponding author: criskano@hotmail.com

Received on: 03/29/2016. Accepted on: 09/04/2017 
Okra (Abelmoschus esculentus (L.) Moench), which has its origin in the African continent, possibly in Ethiopia, is part of the Malvaceae family. It is a semi-woody, annual, shrubby and erect plant that may grow to $3 \mathrm{~m}$ (FILGUEIRA, 2003). Fruits of these leafy vegetables are used in the preparation of typical regional dishes and are rich in vitamins (A and $\mathrm{B}$ ) and minerals (TRANI et al., 2007).

In an experiment on organic production of okra carried out in an experimental area at Embrapa Amazônia Ocidental, Manaus, Amazon state, Brazil, from September 2013 to January 2014, we observed large chlorotic, necrotic, helical, discontinuous, dark or light-brown lesions with partial detachment of the injured area on the adaxial surface of leaves located in the median and basal portions of the plants (Fig. 1). An easily seen whitish mycelium mantle covered the spots on leaves of the abaxial surface at high moisture conditions, which covered the whole colonized area (Fig. 2).

The fungus was isolated using a potato dextrose agar (PDA) medium. The pathogenicity test was made under greenhouse conditions. The mycelium found in the abaxial surface of young okra leaves inoculated the PDA blocks. After the inoculation process, the plants were kept in a humidity chamber for 24 hours. We identified the pathogen based on morphological characteristics, Koch's postulates, and on the ITS-5.8S rDNA sequence region of fungus.

We observed the morphological characteristics in the asexual phase culture grown on the PDA medium and on the basidiospores, by adapting the technique used by TRINDADE et al. (1983) to produce these spores. We used distilled water to wash parts of leaves showing fully developed lesions and containing the pathogen's mycelium on the abaxial surface collected at the field. Then, we took $2-\mathrm{cm}^{2}$ pieces of the lesioned parts of the leaves. Each piece was placed at the inner side of the lid of a Petri dish along with a cotton sliver, and secured using adhesive tape. The leaf's abaxial surface faced the bottom of the dish. After moistening the cotton sliver using

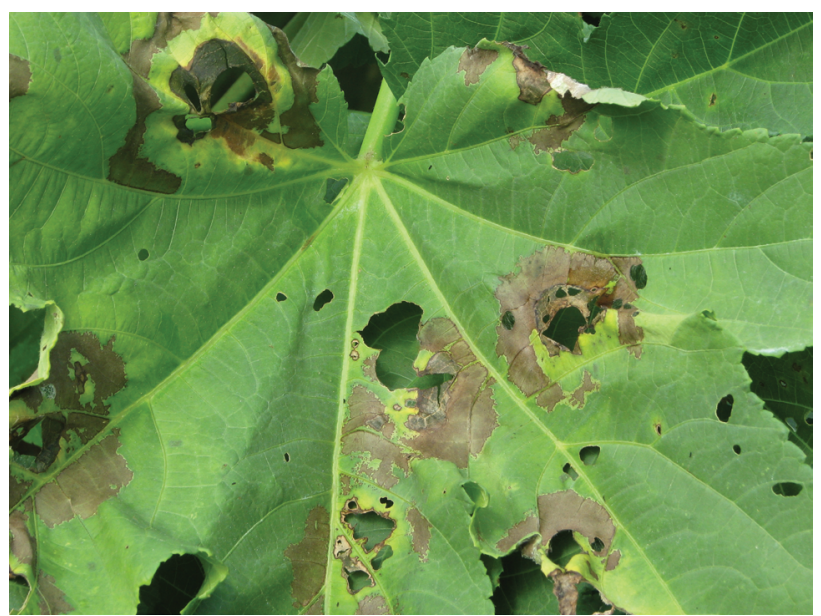

Figure 1. Symptoms of web blight (Thanatephorus cucumeris) on the adaxial surface of okra leaves. sterile water, we placed the lid onto the Petri dish that contained the PDA medium. After preparation, the Petri dishes were incubated at $23^{\circ} \mathrm{C}$ under environmental lighting at the laboratory. Under these conditions, we noticed the ejection of basidiospores after two hours.

PDA-grown hyphae, at their asexual phase, showed wideangle branches (nearly $90^{\circ}$ ) featuring a small constriction at their point of origin, which is a characteristic of Rhizoctonia species. On the pieces of leaves containing the pathogen's mycelium that were placed in the humidity chamber, the hymenium's hyphae produced 6 to $18 \mu \mathrm{m}$ diameter and 9 to $26 \mu \mathrm{m}$ height basidia — from barrel-shaped to cylindrical basidia - arranged individually or in arrays similar to clusters. Each basidium produced an average of four sterigmata (varying from 3 to 7 ), which measured from 35 to $53 \mu \mathrm{m}$ in length. The ejected basidiospores were hyaline, oblong, with a thin and flat wall, and measured 6-13 $\mu \mathrm{m} \times 4-9 \mu \mathrm{m}$.

The pathogenicity test showed symptoms and signs of the pathogen in the third and fifth days after inoculation, respectively. The pathogen was then re-isolated in the PDA medium for confirmation of Koch's postulates.

To obtain the pathogen's phylogenetic position, we determined the rDNA ITS-5.8S sequence region of the fungus. The fungus' lyophilized mycelial DNA was extracted using the Genelute kit (Sigma-Aldrich Brasil), and following the manufacturer's instructions. The DNA extraction procedure was performed in triplicate. To amplify the polymerase chain reaction (PCR) and the rDNA's ITS region sequencing, we applied the ITS4 (5'-TCCTCCGCTTATTGATATGC-3') and ITS5 (5'-GGAAGTAAAAGT CGTAACAAGG-3') pair of primers (WHITE et al., 1990).

The PCR products were sent to Macrogen (Korea) and submitted to a sequencing reaction using the PE Applied Biosystems ABI-3700 automatic sequencer. We analyzed the sequences using the Geneious software (Biomatters Limited,

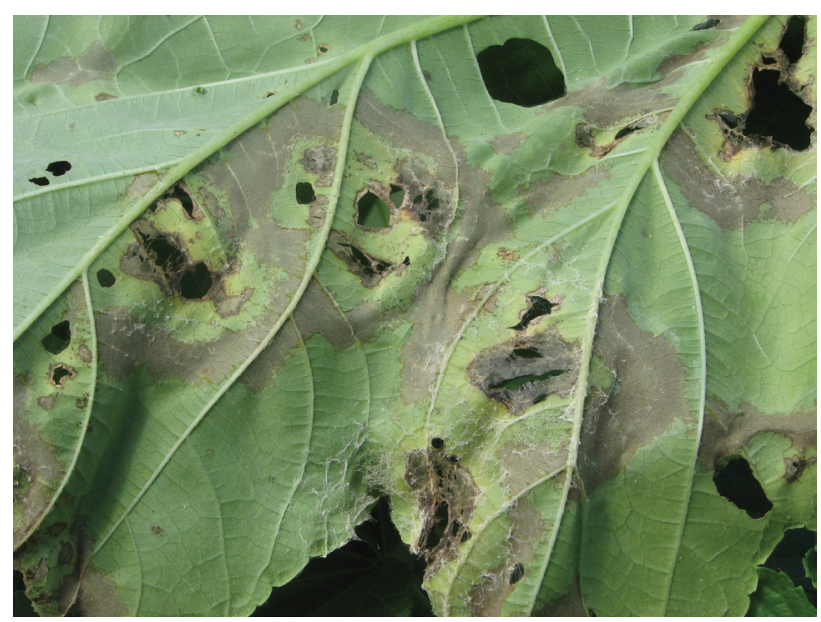

Figure 2. Abaxial surface of an okra leaf showing web blight symptoms and signs of the Thanatephorus cucumeris pathogen that is characterized by the growth of the pathogen's mycelium. 
Table 1. DNA sequences of rDNA's ITS 1-5.8S-ITS2 region from standard isolates of AG-1 and AG-4 HGI complexes from Rhizoctonia solani that is used to determine the phylogenetic position of the pathogen's isolate associated with web blight on okra.

\begin{tabular}{|c|c|c|c|c|c|}
\hline $\begin{array}{l}\text { Anastomosis } \\
\text { group }\end{array}$ & $\begin{array}{l}\text { Sequence code in } \\
\text { GenBank (NCBI) }\end{array}$ & Isolates & Host & Place of origin & Source $^{a}$ \\
\hline AG-1 IA & AB000010 & $1 \mathrm{AA}-10$ & - & Japan & S. Kuninaga \\
\hline$A G-1 \mid A$ & DQ173048 & AGIIArJ & Rice & Switzerland, Zurich & M. B. Ciampi \\
\hline$A G-1 I A$ & AJ000199 & IMI 360366 & - & United Kingdom & A. Johanson \\
\hline$A G-1 I A$ & AJ000200 & IMI 360021 & - & United Kingdom & A. Johanson \\
\hline$A G-1 I A$ & AJO00197 & IMI 358761 & - & United Kingdom & A. Johanson \\
\hline$A G-1$ IA & AF308631 & Cuba2 & Beans & USA, Lincoln & G. Godoy-Lutz \\
\hline$A G-1 I A$ & DQ173047 & AG1IAmJ & Maize & Japan, Tohoku & M. B. Ciampi \\
\hline$A G-1 I A$ & DQ173063 & SJ047 & Soybean & Brazil & M. B. Ciampi \\
\hline$A G-1 \mid A$ & AY270011 & SJ067 & Soybean & Brazil, Goiânia & R.C. Fenille \\
\hline$A G-1 I A$ & DQ173064 & SJ048 & Soybean & Brazil & M. B. Ciampi \\
\hline$A G-1 I A$ & DQ301757 & SJ057 & - & Holland & A.K. Nakatani \\
\hline$A G-1$ IA & AB000016 & $1 \mathrm{ACs}-\mathrm{Gi}$ & - & Japan & S. Kuninaga \\
\hline$A G-1 I A$ & AB000017 & $1 \mathrm{~A} \mathrm{Cs}-\mathrm{Ka}$ & - & Japan & S. Kuninaga \\
\hline$A G-1 \mid A$ & AF354097 & 2Rs & Rice & USA & D. Gonzalez \\
\hline$A G-1$ IA & AF354060 & $1 \mathrm{Rs}$ & Soybean & USA & D. Gonzalez \\
\hline$A G-1$ IB & AB000025 & $1 \mathrm{~B} 001-7$ & - & Japan & S. Kuninaga \\
\hline$A G-1$ IB & AB000038 & 1B SFBV-1 & - & Japan & S. Kuninaga \\
\hline AG- 1 IB & AB000039 & 1B SHIBA- 1 & - & Japan & S. Kuninaga \\
\hline$A G-1$ IC & AF354058 & 3Rs & Pinus & Canada & D. Gonzalez \\
\hline AG-1 IC & EU591807 & $\mathrm{R} 107$ & Cabbage & USA & G. S. Abawi \\
\hline AG- 1 ID & MF497483 & - & Okra (Abelmoschus Esculentus) & Manaus, Brazil & The authors of this paper \\
\hline$A G-1$ ID & $A B 122125$ & RCP 1 & Coffee & Japan & M. Hyakumachi \\
\hline AG-1 ID & $A B 122131$ & RCP15 & Coffee & Japan & M. Hyakumachi \\
\hline AG- 1 ID & $A B 122127$ & RCP4 & Coffee & Japan & M. Hyakumachi \\
\hline$A G-1$ ID & $A B 122130$ & $\mathrm{RCP} 13$ & Coffee & Japan & M. Hyakumachi \\
\hline AG-1 ID & $A B 122132$ & $\mathrm{RCP} 21$ & Coffee & Japan & M. Hyakumachi \\
\hline AG-1 ID & $A B 122126$ & $\mathrm{RCP} 3$ & Coffee & Japan & M. Hyakumachi \\
\hline AG-1 ID & AB 122129 & RCP11 & Coffee & Japan & M. Hyakumachi \\
\hline$A G-1$ ID & $\begin{array}{l}\text { Bel59, Bel60, } \\
\text { Bel61 and Bel7 } 1\end{array}$ & $\begin{array}{l}\text { Bel59, Bel60, } \\
\text { Bel61 e Bel71 }\end{array}$ & Several hosts & Belém, Brazil & L.S.Poltronieri, A.P.S.C. Gaino \\
\hline AG-1 ID & KX674530.1 & SPM3 & - & Philippines & O.Z.A.Rashed \\
\hline AG-1 ID & EF 197798 & SR6 1 & Durio zibethinus (Malvaceae) & Vietnam & T.T.M. Thuan \\
\hline AG-1 ID & KF907725.1 & HGPHO 1-3 & Brassica juncea & Vietnam & G.K.H. Hua \\
\hline$A G-1$ ID & AB 122128 & RCP7 & Coffee & Japan & M. Hyakumachi \\
\hline AG-1 IE & JF946719.1 & L2 & Beans & Los Limones, Honduras & G. Godoy-Lutz \\
\hline AG-1 IE & JF946736.1 & $\mathrm{H} 25$ & Beans & Jamastran, Honduras & G. Godoy-Lutz \\
\hline AG-1 IF & Bel56a, Bel68 & Bel56, Bel68 & Several hosts & Belém, Brazil & L. S. Poltronieri, A.P.S.C. Gaino \\
\hline AG-1 IF & Bel56b & Bel56 & Several hosts & Belém, Brazil & L. S.Poltronieri, A.P.S.C. Gaino \\
\hline AG-1 IF & JF946727.1 & PR0671 & Beans & La Isabela, Porto Rico & G. Godoy-Lutz \\
\hline AG-4 HGI (b) & AB000018 & HG-I GM-3 & - & Japan & S. Kuninaga \\
\hline AG-4 HGI (b) & AB000007 & HG-I 78-23R-3 & - & Japan & S. Kuninaga \\
\hline AG-4 HGI (b) & $\begin{array}{l}\text { Bel54, Bel64b } \\
\text { and Bel66 }\end{array}$ & $\begin{array}{c}\text { Bel54, Bel64 and } \\
\text { Bel66 }\end{array}$ & Several hosts & Belém, Brazil & L. S Poltronieri, A.P.S.C. Gaino \\
\hline AG-4 HGI (b) & $\begin{array}{l}\text { Bel62a, Bel62b } \\
\text { and Bel64a }\end{array}$ & Bel62 and Bel64 & Several hosts & Belém, Brazil & L. S. Poltronieri, A.P.S.C. Gaino \\
\hline
\end{tabular}

aSequences of rDNA's ITS-5.8S from standard isolates obtained from: A. Johanson, Pest Management Department, Natural Resources Institute, Central Avenue, Chatham Maritime, Chatham, Kent, ME4 4TB, United Kingdom; A. K. Nakatani, Comparative Genomics and Bioinformatics, Centraalbureauvoor Schimmecultures-Fungal Biodiversity Center, Uppsalalaan 8, Utrecht 3584CT, Holland; A. P. S. C. Gaino, UNESP - Campus de Ilha Solteira, Depto. Fitos., Eng. Rural e Solos, Ilha Solteira, SP, Brazil; D. E. Gonzáles, Sistematica Vegetal, Instituto de Ecologia, A. C., Km 2.5 Antigua Carretera a Coatepec, Xalapa, Veracruz 91000, Mexico; G. Godoy-Lutz, Plant Pathology, University of Nebraska-Lincoln, 406 Plant Sciences Hall, Lincoln, NE 68583-0722, USA; G. S. Abawi, Department of Plant Pathology, Cornell University, New York State Agric. Exp. Station, Geneva, 14456, USA; G. K. H. Hua, Crop Protection, Ghent University, Coupure Links 653, Ghent 9000, Belgium; L. S. Poltronieri, EMBRAPA Amazonia Oriental, Belém, Pará, Brazil; M. B. Ciampi, UNESP Campus de Jaboticabal, Depto. Tecnologia, Jaboticabal, SP, Brazil; M. Hyakumachi, Gifu University, Faculty of Agriculture; Yanagido 1-1, Gifu, Gifu, 5011193, Japan; O. Z.A.Rashed, Plant Protection, Faculty of Agriculture, University Putra Malaysia, Serdang, Selangor, Malaysia; R. C. Fenille, Ministério da Agricultura, Goiás, Brazil; S. Kuninaga, Health Sciences University of Hokkaido; Tohbetsu, 1757, Ishikari-gun, Hokkaido 061-0293, Japan; T. T. M. Thuan, Department of Plant Protection, Nong Lam, University, Hochiminh 84, Vietnam; 'Used as outgroup. 
New Zealand), to determine quality and to edit. Then, we aligned them using the ClustalX software (THOMPSON et al., 1997), and we finally compared them to sequences of the rDNA's ITS region from all $R$. solani's anastomosis groups deposited in the GenBank (NCBI) database. We searched for similar sequences using BLASTN (nucleotide-nucleotide), version 2.2.27 from September 10, 2012 (ALTSCHUL et al., 1997). The isolate's sequence was coded MF 497483 in the GenBank. Due to its similarity to sequences of the rDNA's ITS-5.8S region of $R$. solanis AG-1 anastomosis group, we conducted a phylogenetic analysis comparing the AG-1 IA,
IB, IC, ID, IE and IF groups - already described in Brazil —, using $R$ solanis AG-4 HGI as an outgroup, for the tree rooting. The sequences used are described in Table 1 . The phylogenetic analysis was performed using the Geneious R9.1.8 software and its tool Geneious Tree Builder, as well as the HKY evolution model and the UPGMA method to build the tree. To obtain the consensus phylogenetic tree, data were resampled through bootstrapping with 1,000 replicates.

Considering the morphologic characteristics and the phylogenetic position of the okra isolate's rDNA ITS-5.8S region (Fig. 3), which features sequences identical to AG1 ID,

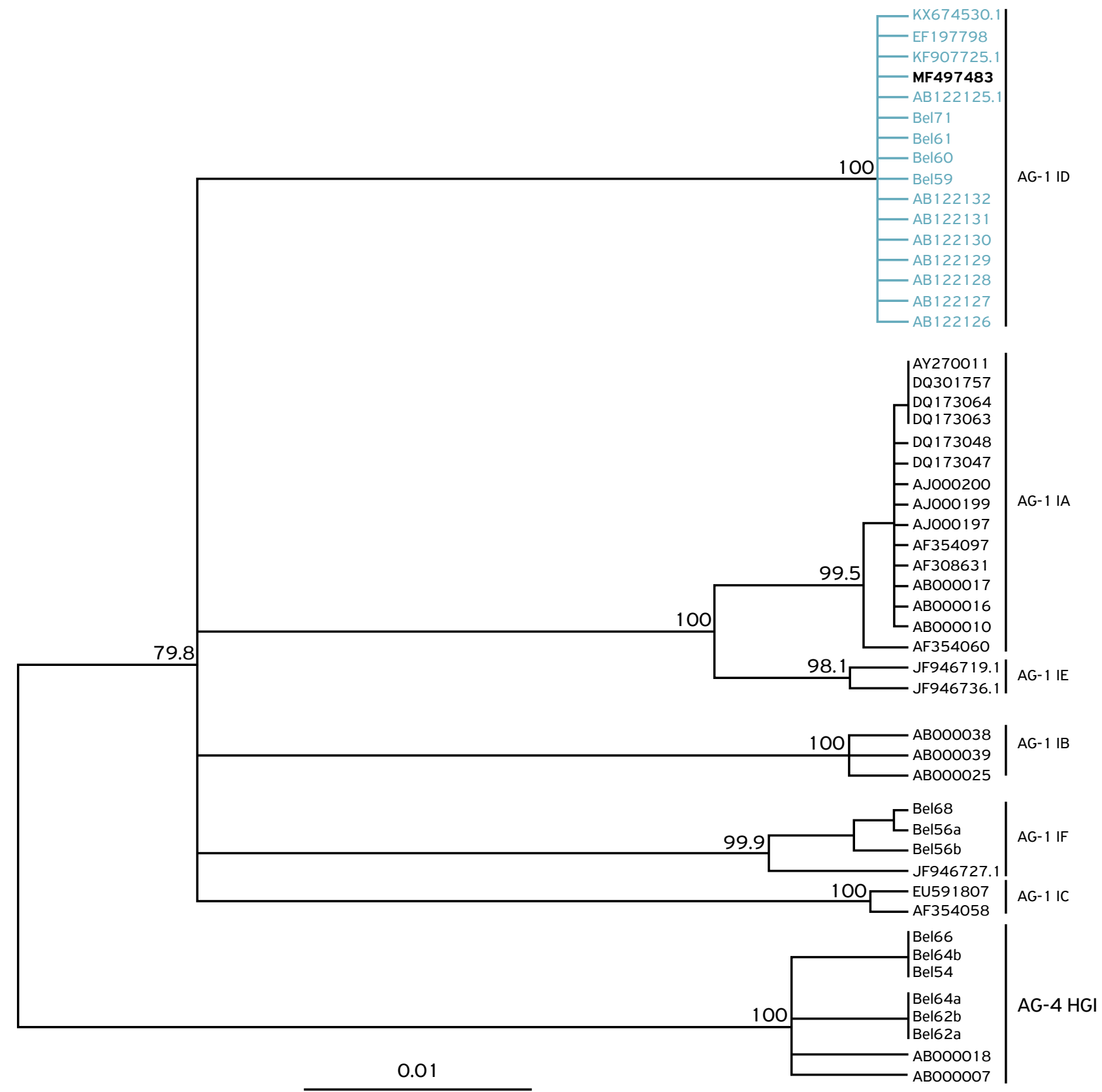

Figure 3. Phylogenetic analysis (UPGMA distance) of the rDNA's ITS-5.8S region from Rhizoctonia solani isolates of the AG- 1 anastomosis group (AG-1 IA, IB, IC, ID, IE and IF) to identify the isolate associated with web blight on okra (MF497483 sequence, in bold) at Manaus, Brazil. Sequences obtained from $R$. solani AG-4 HGI isolates were used as outgroup. Consensus tree was obtained by bootstrap for 1,000 replicates. The values in branches indicate the bootstrap support in percentage. 
T. cucumeris (asexual phase of $R$. solani AG-1 ID) was the fungus identified as the agent causing the disease. This is the first report of an association between $R$. solani AG-1 ID and okra. The occurrence of $R$. solani AG-1 ID as a pathogen associated with web blight, however, was reported in Amazonia during an association with passion fruit (Passiflora edulis f. flavicarpa Deg., Bel59 isolate), beans (Phaseolus vulgaris L., Bel60), shellflower [Alpinianutans (L.) Roscoe, Bel61], and black pepper (Piper nigrum L., Bel71) in 2010 (GAINO et al., 2010).

In the Amazon, T. cucumeris causes web blight in several hosts, such as Para rubber tree (Hevea spp.) (DESLANDES, 1944) and orange (Citrus spp.) (LOURD et al., 1984). According to CAMPOS (2006) and GAINO et al. (2010), the Para rubber tree hosts several other anastomosis groups (AGs), among them AG2-2 Hb, the most frequent one, and AG-1 1D and AG-1 IF (recently reclassified, now encompasses isolates previously classified as AG-1 IB). These isolates infect Para rubber tree and occur in other hosts (native or in crops). This wide array of hosts reflects the pathogen's potential to infect different crops.

In okra, the pathogen had been reported to cause pre- and post-emergence rots, damping off (MASSOLA;
BEDENDO, 2005), and post-harvest fruit rots (HENZ et al., 1996). A strong attack of T. cucumeris happened throughout the okra plant's developmental stages, causing defoliation. It was more frequent during the rainy period (from January to May), when the conditions for infection are more favorable.

This is the first report of T. cucumeris causing web blight and strong defoliation in okra in Brazil, and probably in the world.

\section{ACKNOWLEDGEMENTS}

The authors would like to thank the Amazonas Research Foundation (Fundação de Amparo à Pesquisa do Estado do Amazonas - FAPEAM), for the financial aid provided to this study; the Conselho Nacional de Desenvolvimento Científico e Tecnológico (CNPq), for the Pq2 fellowship (CNPq protocol n. 307295/2015-0); the Fundação de Amparo à Pesquisa do Estado de São Paulo, for the financial aid to obtain the samples and the data on rDNA's ITS-5.8S sequences from isolates associated with web blight in the Amazon (FAPESP process n. 2004/02127-9).

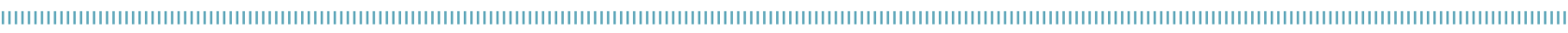

\section{REFERENCES}

ALTSCHUL, S.; MADDEN, T.; SCHÄFFER, A.; ZHANG, J.; ZHANG Z.; MILLER, W.; LIPMAN, D. Gapped BLAST and PSI-BLAST: a new generation of protein database search programs. Nucleic Acids Research, v.25, p.3389-3402, 1997. Available from: <http:// nar.oxfordjournals.org/cgi/content/abstract/25/17/3389>. Accessed on: 01 mar. 2016.

CAMPOS, A.P.S. A complexa etiologia da mancha areolada de Thanatephorus sp. e/ou Ceratobasidium sp. em espécies cultivadas ou nativas da Amazônia. 2006. 70f. Dissertation (Mestrado em Agronomia - Sistemas de Produção) - Universidade Estadual Paulista “Júlio de Mesquita Filho”, Ilha Solteira, 2006.

DESLANDES, J.A. Observações fitopatológicas na Amazônia. Boletim Fitossanitário, Rio de Janeiro, v. 1, n.3/4, p.197-242, 1944

FILGUEIRA, F.A.R. Novo manual de olericultura: agrotecnologia moderna na produção de hortaliças. 2. ed. Viçosa: UFV, 2003.412p.

GAINO, A.P.S.C.; BASSETO, M.A.; GASPAROTTO, L.; POLTRONIERI, L.S.; CERESINI, P.C. Interferência filogenética revela a complexa etiologia das manchas areolada e foliar em seringueira e em outras espécies cultivadas na Amazônia. Acta Scientiarum Agronomy, Maringá, v.32, n.3, p.385-395, 2010.

HENZ, G.P.; NOJOSA, G.B.A.; MENDONÇA, N.D. Ocorrência de Rhizoctonia solani como patógeno pós-colheita em frutos de quiabo. Horticultura Brasileira, Brasília, v. 14, p.89, 1996.
LOURD, M.; BRAZ ALVES, M.L.; GASPAROTTO, L. Ocorrência da mancha areolada em citrus no município de Manaus-AM. Fitopatologia Brasileira, Brasília, v.9, p. 135, 1984.

MASSOLA, J.R., N.S.; BEDENDO, I.P. Doenças do quiabeiro (Abelmoschus esculentus). In: KIMATI, H.; AMORIM, L.; REZENDE, J.A.M.; BERGAMIN FILHO, A.; CAMARGO, LE.A. Manual defitopatologia: doenças das plantas cultivadas. São Paulo: Agronômica Ceres, 2005. v.2. p.541-543.

THOMPSON, J.; GIBSON, T.; PLEWNIAK, F.; JEANMOUGIN, F.; HIGGINS, D. The clustal_X windows interface: flexible strategies for multiple sequence alignment aided by quality analysis tools. Nucleic Acids Research, v.25, p.4876-4882, 1997.

TRANI, P.E.; PASSOS, A.F.; MELO, A.M.T. de; BOVI, O.A.; PIMENTEL, E.C. Hortaliças e plantas medicinais: manual prático. Campinas: Instituto Agronômico. 2007. 72p. (Série Tecnologia APTA, Boletim Técnico IAC, 199).

TRINDADE, D.R.; GASPAROTTO, L.; SILVA, H.M. Produção de basidiósporos de Thanatephorus cucumeris, agente causal da mancha areolada na seringueira. Fitopatologia Brasileira, Brasília, v.8, n.3, p.611, 1983

WHITE, T.J.; BRUNS, T.; LEE, S.; TAYLOR, J.W. Amplification and direct sequencing of fungal ribosomal RNA genes for phylogenetics. In: INNIS, M.A.; GELFAND, D.H.; SNINSKY, J.J.; WHITE, T.J. PCR protocols: a guide to methods and applications. New York: Academic Press Inc., 1990. p.315-322. 